\title{
Effect of Methyl Jasmonate on Growth and Flowering Behavior of Strawberry cv. Nabila
}

\author{
Lalnunzawma $^{1}$, Kumari Karuna ${ }^{1 *}$, Ruby Rani ${ }^{1}$, \\ Sareeta Nahakpam ${ }^{2}$, Subrat Keshori Bahera ${ }^{3}$ and Sanjay Sahay ${ }^{1}$ \\ ${ }^{1}$ Department of Horticulture (Fruit \& Fruit Tech.), BAC, Sabour, Bihar, India \\ ${ }^{2}$ Department of Biochemistry and Crop Physiology, BAC, Sabour, Bihar, India \\ ${ }^{3}$ Department of SMCA, BAU, Sabour, Bihar, India
}

*Corresponding author

\begin{tabular}{l} 
Ke y w o r d s \\
Methyl jasmonate, \\
Growth and \\
flowering behavior, \\
Strawberry \\
Article Info \\
$\begin{array}{l}\text { Accepted: } \\
18 \text { August } 2020 \\
\text { Available Online: } \\
\text { 10 September } 2020\end{array}$ \\
\hline
\end{tabular}

\section{A B S T R A C T}

The experiment was laid out in the year 2019-2020 at Bihar Agricultural University, Sabour to show the application of different doses of methyl jasmonate on growth and flowering behavior of strawberry cv. Nabila. The plant under treatment $\mathrm{T}_{3}(0.6 \mathrm{mM})$ was found the tallest $(21.25 \mathrm{~cm})$, highest leaf area $\left(33.59 \mathrm{~cm}^{2}\right)$, The relative water content in the leaves $(55.62 \%)$, maximum number of leaves (28.33 per plant) while the all above parameters recorded minimum value under control. Similarly, the highest no. of flowers per plant (37.65 flowers) was found under treatment $T_{3}$ whereas lowest number under $\mathrm{T}_{1}$ (25.67 flowers). The least no. of days (56.24 days) were found for first flowering under treatment $T_{3}$ while the plants under $T_{1}$ required the most days (57.27 days). The plants under $T_{1}$ took the longest (64.50 days) for their first fruit setting while the $T_{3}$ took the shortest (60.21 days). Longest harvesting period was found under plants of $\mathrm{T}_{3}$ (80.50 days) while the shortest duration under $\mathrm{T}_{1}$ (60.30 days).

\section{Introduction}

Strawberry (Fragaria $\mathrm{x}$ ananassa Duch) is a man-made hybrid developed by crossing Fragaria chiloensis and Fragaria virginiana, which then become one of the most important soft fruits in the world. The fruit is consumed fresh and processed in many different products, making it to be in highly demand due to its rich flavour and aroma, excellent visual and quality. The fruits are not only rich in its taste, but also rich in vitamins and minerals to which many people around the globe include it in their daily diet. For better growth and flowering behaviour of strawberry plants, it require special treatments of different chemicals. The use of different plant growth regulators is a common practice in 
different crops in order to get better growth and yield from the crop. The exogenous application of PGRs has been found to stimulate the growth, flowering and fruiting of different fruit crops (Al-Duljaili et al., 1987; Randhawa et al., 1959) which resulted from the improvement of endogenous level of phytohormone and mineral nutrients (Bist, 1990). Among different PGRs, Methyl Jasmonate, a methyl ester of Jasmonic Acid is a phytohormone with ubiquitous distribution among plants and generally considered to modulate many physiological events in higher plants, such as defense responses, flowering and senescence (Cheong and Choi, 2003). Some reports also suggest that methyl jasmonate plays an important role in defense mechanism of plants and diverse developmental pathways such as seed germination, root growth, etc. However, literatures on the exact response of methyl jasmonate on strawberry plants and fruits to improve the yield and quality is still exiguous as the use of this compound is still uncommon for the improvement of crops in experiments or cultivation practices, particularly on the shelf life of the fruits. Therefore, more experiments are required on this field to study its function on various parameters of the plant, especially under sub-tropical condition.

\section{Materials and Methods}

The experiment was conducted in Horticulture Garden, Bihar Agricultural College, Sabour, Bhagalpur, Bihar during the year 2019-2020 in Randomized Block Design with four treatments and five replications for the investigation of growth and flowering behavior of strawberry plants cultivar Nabila. The four treatments of methyl jasmonate were $\mathrm{T}_{1}$ (Control), $\mathrm{T}_{2}(0.3 \mathrm{mM}), \mathrm{T}_{3}(0.6 \mathrm{mM})$ and $\mathrm{T}_{4}(0.9 \mathrm{mM})$. The plants were sprayed in two stages during their growth, viz., prior to flowering and 15 days after the first spray. Meteorological observation during cropping season 2019-20 given in Table 1.

\section{Growth parameters}

\section{Plant height}

The plant height was measured by erecting the measuring scale from the bottom to the maximum height of the plant for three different tagged plants under each replication and the average plant height for each replication was calculated.

\section{Number of leaves per plant}

The number of leaves in a plant was measured by counting the total number of leaves produced per plant for three different tagged plants under each replication and average number of leaves per plant for each replication was calculated.

\section{Leaf relative water content ( $\mathrm{RWC} \%$ )}

The relative water content of the mature leaves was measured following the method suggested by Weatherley (1950). According to this method, fresh leaf samples were collected and $1 \mathrm{~cm}^{2}$ size were cut off from the leaf samples. Fresh weight of these cutoff samples was then taken and was imbibed by floating them in distilled water inside a petri dish overnight.

After imbibing for overnight, the samples were then surface dried with filter paper and were re-weighed before being oven-dried. After that, the samples were dried in an oven dryer at $70^{\circ} \mathrm{C}$ for $24 \mathrm{hrs}$. The weight of the dried samples was then taken. The relative water content (RWC) is calculated by using the formula:

\section{RWC $(\%)=$}

Fresh weight-Dry weight

Turgid weight-Dry weight $\mathrm{x} 100$ 


\section{Leaf area $\left(\mathrm{cm}^{2}\right)$}

The area of leaves was measured with the help of graph paper during their growing period just prior to second spray of the solution, i.e., 14 days after first spray.

\section{Reproductive growth}

\section{Days of first flowering}

It was measured by counting the total number of days taken by the plant for anthesis of first flower from the date of planting.

\section{Total number of flowers per plant}

It was measured by counting the total number of flowers produced by the plants during the entire flowering period.

\section{Days to first fruit setting}

It was measured by counting the days taken by the plants to set fruits from the date of planting.

\section{Duration of harvesting}

It was recorded by counting the total number of days taken by the plant in each replication under each treatment from harvesting of first fruit to last fruit and expressed in days.

\section{Statistical analysis}

The experimental data were subjected to statistical analysis in order to find out which of the treatments showed significant variation in different parameters studied under investigation.

The technique of analysis of variance (ANOVA) for randomized block design (RBD) was adopted as suggested by Panse and Sukhatme (1967).

\section{Results and Discussion}

\section{Growth parameters}

The plant height of different MeJA treated strawberry fruits has been found nonsignificant but in respect of leaf area it was significant differences among the treatments (Table 2). It was found highest $\left(33.59 \mathrm{~cm}^{2}\right)$ under plants treated with $0.6 \mathrm{mM} \mathrm{MeJA}\left(\mathrm{T}_{3}\right)$ and lowest $\left(27.66 \mathrm{~cm}^{2}\right)$ under control $\left(\mathrm{T}_{1}\right)$. The relative water content of plants treated with different doses of MeJA was found statistically significant among the treatments and it was showed highest $(75.27 \%)$ with 0.6 $\mathrm{mM}\left(\mathrm{T}_{3}\right)$ while the untreated plants $\left(\mathrm{T}_{1}\right)$ have the least $(55.62 \%)$. The data for no. of leaves per plant under MeJA treatment was recorded non-significant. Vegetative growth was not much more affected by MeJA treatments. The value of two parameters i.e. plant height and number of leaves per plant were showed no any effect till higher concentration but in other two parameters i.e leaf area and RCW the value increases upto the concentration of $0.6 \mathrm{mM} \mathrm{MeJA}$ and decreases in higher concentration $(0.9 \mathrm{mM})$. This might be due to higher concentration adversely affected the vegetative growth in strawberry plants. These results are in conformity with the findings of Lolaei et al., (2013) in strawberry. Rahimi et al., (2013) were also found better result in growth attributes with lower concentration in Cuminum cyminum $\mathrm{L}$. and $\mathrm{Cui} \mathrm{Li}$ et al., (2018) on sunflower, tomato and soybean.

\section{Flowering behaviours}

The plants treated with MeJA have not responded positively in respect of number of days for initiation of first flowering. The number of flowers per plant in strawberry cv. Nabila under different doses of MeJA treatment was significant in nature. Plants treated with $0.6 \mathrm{mM}$ MeJA $\left(\mathrm{T}_{3}\right)$ had 37.65 flowers which was followed by $\mathrm{T}_{4}(31.00)$ 
and $\mathrm{T}_{2}$ (29.70) while the minimum (25.67) in control $\left(\mathrm{T}_{1}\right)$. The data in respect of number of days for the first fruiting in strawberry cv. Nabila was found to be non-significant. The data for duration of harvest was found significant among the treatments. The maximum duration of harvest (80.50 days) was recorded with the $0.6 \mathrm{mM} \mathrm{MeJA}\left(\mathrm{T}_{3}\right)$ treated plants which was statistically differed from other treatments. The minimum duration of harvest (60.30 days) was under control (Table 3).

Table.1 Meteorological observation during cropping season 2019-20

\begin{tabular}{|c|c|c|c|c|c|c|c|c|}
\hline \multirow[t]{2}{*}{ Month } & \multicolumn{2}{|c|}{$\begin{array}{c}\text { Temperature } \\
\left({ }^{\circ} \mathrm{C}\right)\end{array}$} & \multicolumn{2}{|c|}{$\begin{array}{c}\text { Relative } \\
\text { humidity }(\%)\end{array}$} & \multirow[t]{2}{*}{$\begin{array}{c}\text { Rainfall } \\
\text { (mm) }\end{array}$} & \multirow{2}{*}{$\begin{array}{c}\text { Wind } \\
\text { speed } \\
(\mathbf{k m} / \mathbf{h r})\end{array}$} & \multirow[t]{2}{*}{$\begin{array}{c}\text { Sunshine } \\
\text { (hrs) }\end{array}$} & \multirow[t]{2}{*}{$\begin{array}{c}\mathbf{E P} \\
(\mathbf{m m})\end{array}$} \\
\hline & Max. & Min. & $\begin{array}{l}7: 00 \\
\text { AM }\end{array}$ & $\begin{array}{l}\text { 2:00 } \\
\text { PM }\end{array}$ & & & & \\
\hline Nov. 2019 & 28.9 & 16.2 & 87.6 & 76.1 & 0.0 & 2.1 & 3.3 & 1.1 \\
\hline Dec. 2019 & 21.2 & 9.3 & 91.4 & 75.9 & 2.5 & 3.9 & 3.5 & 0.6 \\
\hline Jan. 2020 & 21.9 & 8.8 & 93.0 & 71.0 & 6.0 & 4.2 & 4.5 & 1.0 \\
\hline Feb. 2020 & 24.1 & 9.7 & 88.4 & 66.7 & 38.4 & 3.6 & 6.5 & 1.6 \\
\hline Mar. 2020 & 30.5 & 16.8 & 86.6 & 59.1 & 48.0 & 4.6 & 6.7 & 3.5 \\
\hline
\end{tabular}

Table.2 Effect of MeJA on growth parameters

\begin{tabular}{|c|c|c|c|c|c|}
\hline Sl. No. & Treatments & $\begin{array}{c}\text { Plant height } \\
(\mathbf{c m})\end{array}$ & $\begin{array}{c}\text { Leaf area } \\
\mathbf{( c m}^{\mathbf{2}} \mathbf{)}\end{array}$ & $\begin{array}{c}\text { Leaf RWC } \\
(\mathbf{\%})\end{array}$ & $\begin{array}{c}\text { No. of leaves } \\
\text { per plant }\end{array}$ \\
\hline $\mathbf{T}_{\mathbf{1}}$ & Control & 19.00 & 27.66 & 55.62 & 24.26 \\
\hline $\mathbf{T}_{\mathbf{2}}$ & $0.3 \mathrm{mM} \mathrm{MeJA}$ & 19.67 & 31.21 & 69.46 & 26.67 \\
\hline $\mathbf{T}_{\mathbf{3}}$ & $0.6 \mathrm{mM} \mathrm{MeJA}$ & 21.25 & 33.59 & 75.27 & 28.33 \\
\hline $\mathbf{T}_{\mathbf{4}}$ & $0.9 \mathrm{mM} \mathrm{MeJA}$ & 20.42 & 30.32 & 68.76 & 25.00 \\
\hline & $\mathrm{SE} \pm(\mathrm{m})$ & 0.073 & 0.112 & 0.172 & 0.097 \\
\hline & $\mathrm{CD}(\mathrm{P}=0.05)$ & $\mathrm{NS}$ & 0.350 & 0.535 & $\mathrm{NS}$ \\
\hline
\end{tabular}

Table.3 Effect of MeJA on flowering behaviours

\begin{tabular}{|c|c|c|c|c|c|}
\hline Sl. No. & Treatments & $\begin{array}{c}\text { First } \\
\text { flowering } \\
\text { (days) }\end{array}$ & $\begin{array}{c}\text { No. of } \\
\text { flowers per } \\
\text { plant }\end{array}$ & $\begin{array}{c}\text { First fruiting } \\
\text { (days) }\end{array}$ & $\begin{array}{c}\text { Duration of } \\
\text { harvest } \\
\text { (days) }\end{array}$ \\
\hline $\mathbf{T}_{\mathbf{1}}$ & Control & 57.27 & 25.67 & 64.50 & 60.30 \\
\hline $\mathbf{T}_{\mathbf{2}}$ & $0.3 \mathrm{mM} \mathrm{MeJA}$ & 56.76 & 29.70 & 63.40 & 72.28 \\
\hline $\mathbf{T}_{\mathbf{3}}$ & $0.6 \mathrm{mM}$ MeJA & 56.24 & 37.65 & 60.21 & 80.50 \\
\hline $\mathbf{T}_{\mathbf{4}}$ & $0.9 \mathrm{mM} \mathrm{MeJA}$ & 56.46 & 31.00 & 62.52 & 66.14 \\
\hline & $\mathrm{SE} \pm(\mathrm{m})$ & 0.170 & 0.145 & 0.162 & 0.205 \\
\hline & $\mathrm{CD}(\mathrm{P}=0.05)$ & $\mathrm{NS}$ & 0.451 & $\mathrm{NS}$ & 0.638 \\
\hline
\end{tabular}

According to Toby et al., 2010 MeJA affects growth of the plant and many flowering behaviours depending on the mycorrhizal or nonmycorrhizal association in the plants. It was also found that MeJA had no significant effect on floral traits in nonmycorrhizal 
plants. Above results suggested that jasmonate group response on presence of mycorrhiza and nutrient status in the plant. In fact, the benefits of mycorrhization for floral traits and pollination behaviour documented in various greenhouse studies (Gange and Smith 2005; Wolfe, Husband and Klironomos 2005) and in the field (Cahill et al., 2008) were lost in our experiment after MeJA application. Mycorrhizal plants treated with MeJA had floral traits comparable to nonmycorrhizal plants. The mechanism of this result is unknown and requires further study; MeJA could have direct effects on the AMF in terms of reduced growth and allocation to reproductive structures (Schmidt and Baldwin 2006).

Hence concluded, in case of growth parameters of strawberry, MeJA treatments had influence positively upto the concentration of $0.6 \mathrm{mM}$ MeJA then after decline. Flowering behaviors also influenced positively upto $0.6 \mathrm{mM} \mathrm{MeJA}$ and then adversely affected. So, on the basis of above results it may be concluded that the MeJA treatment with $0.6 \mathrm{mM}$ concentrations was found to be the best result.

\section{References}

Al-Duljaili, J.A., Al-Khafaji, M.A. and AlJuboory, K.H. (1987). The effect of localized GA3 application on the yield and quality of 'Thompson Seedless' grape (Vitis vinifera L.). Iraqi Journal of Agricultural Science, 5: 51-57.

Bist, L.D. (1990). Influence of PP333, Alar, CCC and Promalin on macronutrient status of pear leaf. Acta Horticulturae, 274: 43-50.

Cahill, J.F., Elle, E., Smith, G.R. and Shore, B.H. (2008) Disruption of a belowground mutualism alters interactions between plants and their floral visitors. Ecology 89: 1791-1801.
Cheong, J.-J. and Choi, Y.D. (2003). Methyl jasmonate as a vital substance in plants. Trends in Genetics. 19: 409-413.

Cui Li, Peng Wang, Neal W. Menzies, Enzo Lombi, and Peter M. Kopittke (2018) Effects of methyl jasmonate on plant growth and leaf properties J. Plant Nutr. Soil Sci. 181, 409-418

Cui Li, Peng Wang, Neal W. Menzies, Enzo Lombi and Peter M. KopCui, J., Bahrami, A.K., Pringle, E.G., Hernandez-Guzman, G., Bender, C.L., Pierce, N.E. and Ausubel, F.M. (2005) Pseudomonas syringae manipulates systemic plant defenses against pathogens and herbivores. Proceedings of the National Academy of Sciences of the United States of America, 102: 1791- 1796.

Gange, A.C. and Smith, A.K. (2005) Arbuscular mycorrhizal fungi influence visitation rates of pollinating insects. Ecological Entomology 30: 600-606.

Lolaei, A., Zamani, S., Mobasheri, S., Ahmadian, E. (2013) Effects of methyl jasmonate application on some characteristics in strawberry cultivars (Camarosa and Queen Elisa). International Journal of Agriculture and Crop Sciences 5 (8):845-851.

Panse, V.G. and Sukhatme, P.V. (1967) Statistical methods for agricultural workers, Indian Council of Agricultural Research, New Delhi.

Rahimi, Abdol Rahman, Rokhzadi Asad, Amini Sheno, Karami Ezzat (2013) Effect of salicylic acid and methyl jasmonate on growth and secondary metabolites in Cuminum cyminum $\mathrm{L}$. Journal of Biodiversity and Environmental Sciences, 3(12): 140149.

Randhawa, J.S., Singh, J.P. and Khanna, K.C. (1959). Effect of gibberellic acid and some other plant growth regulators on fruit set, quality and yield of phalsa. 
Indian Journal of Horticulture, 16: 202205.

Schmidt, D.D. and Baldwin, I.T. (2006) Transcriptional responses of Solanum nigrum to methyl jasmonate and competition: a glasshouse and field study. Functional Ecology, 20, 500 508 .

Toby Kiers Lynn E., S. Adler, Emily L. Grman and Marcel G. A. van der Heijden (2010) Manipulating the jasmonate response: How do methyl jasmonate additions mediate characteristics of aboveground and belowground mutualisms? Functional Ecology 24: 434-443

Weatherley, P.E. (1950). Studies in the water relations of the cotton plant. I. The field measurement of water deficits in leaves. New Phytologist, 49: 81-87.

Wolfe, B.E., Husband, B.C. and Klironomos, J.N. (2005) Effects of a belowground mutualism on an aboveground mutualism. Ecology Letters 8: 218223.

\section{How to cite this article:}

Lalnunzawma, Kumari Karuna, Ruby Rani, Sareeta Nahakpam, Subrat Keshori Bahera and Sanjay Sahay. 2020. Effect of Methyl Jasmonate on Growth and Flowering Behavior of Strawberry cv. Nabila. Int.J.Curr.Microbiol.App.Sci. 9(09): 2690-2695. doi: https://doi.org/10.20546/ijcmas.2020.909.335 